\title{
くひろば >
}

\section{脂質性の栄養成分および原材料名の表示について

\author{
日本脂質栄養学会 食用油脂安全性委員会 委員長 \\ 大原 直樹*
}

\section{On Lipid Nutrition and Ingredient Labeling}

\author{
Naoki Ohara \\ Committee of lipid safety \\ Japan society for lipid nutrition
}

\section{Summary}

Consumer interest in foods and food safety has been increasing recently, and food-related information is easily available on demand. While nutrition and ingredient labeling of food should, in the first place, be easily intelligible to any consumer, current nutrition labeling in Japan is voluntary and does not necessarily present information helpful for consumers. Thus, providing accurate information to allow adequate and safe ingestion of lipids via ingredient labeling is one of our first priorities. We have, accordingly, decided to approach the national government with a proposal to improve the current labeling standards. The following article, "Improvements we seek in lipid nutrition and ingredient labeling and the reasons for our proposal ----- including problems in current lipid nutrition ingredient labeling and an explanation of the need for change -----" is to be attached to the proposal. The purpose of this article is to provide adequate grounds for proposing changes in labeling, and we would invite suggestions and comments on this article from subscribers concerned with lipid nutrition and ingredient labeling of food, for our consideration.

\footnotetext{
* 金城学院大学薬学部

干463-8521 名古屋市守山区大森二丁目 1723

電話: 052-798-0180、FAX: 052-798-0754

Email: oharan@kinjo-u.ac.jp
} 


\section{[はじめに $]$}

食品栄養成分表示は、第一に消費者にとって分かり易いものでなければなりません が、現在の表示は必ずしもそうではありません。そこで、日本脂質栄養学会では、食 品栄養成分（脂質）表示を一般消費者に分かり易いものにするよう、関係省庁に改善 を働きかけていくことになりました。ここに掲載する「改正を求める栄養成分（脂 質）表示の項目とその必要性について」（原材料名（脂質性）表示の問題点と改正の 必要性についての説明を含む）は、要望書を提出する際に添付し、その根拠を示す目 的で、本会食用油脂安全性委員会がまとめたものです。本会会員はもとより、本誌読 者諸氏にご一読いただき、ご意見を募り、要望書に反映させたいと考えております。

\section{[背景]}

食の安全に対する消費者の意識は高まり、求めれば新しい情報を得ることも容易に なってきた現在、例えば、n-6 脂肪酸の摂り過ぎと炎症性疾患の関連は、健康意識の 高い消費者には広く知られるようになっています。このような時代にあって、栄養学 的に適切で、より安全な油脂の摂取に関寸る情報を提供するとともに、それらの情報 に基づいて消費者が自身の判断によって製品選択をする際、拠り所になり得る栄養成 分表示への改善を求めていくことは、「時代に即応した脂質栄養指針を確立し、それ に基づいた脂質性食品供給方法の開発を図り、もって健康の維持増進に寄与する。」 という、日本脂質栄養学会会則第 2 条に掲げる目的に沿う重要な活動の一つです。

食用油脂の健康影響については、上述の脂肪酸組成に関わるもののほか、トクホ植 物油製品中に見出されて問題となったグリシドール、水素添加油脂に含まれるトラン ス脂肪酸など、製造過程で生じる副生物の生理作用にも眼を向ける必要があります。 また、現在汎用されている食用油のいくつかは、実験動物が攝取した場合に様々な有 害効果を示すことが確認されています。提起されている食用油脂の安全性・有害性を ヒトで確認することは困難な場合が多いのですが、食経験によってヒトでの安全性が 担保されていると考えることも出来ません。動物で有害事象が比較的低用量で確認さ れている場合、単純に動物実験の結果であるという理由で無視するのではなく、ヒト への健康影響を考慮にいれる慎重さも必要です。 
このような背景から本委員会は、食用油脂の安全性に関する情報の提供を進めると ともに、消費者に分かり易い栄養成分表示を求めていきます。例えば食用植物油ある いは植物油脂と一括して表示することを改め、由来植物名（油種）を明示する等、消 費者に分かり易い表示をして、消費者の判断に基づいた商品選択を促すことが、偏っ た食用油脂の摂取による健康影響を回避する大切な手段であると考えるからです。

なお、本稿へのご意見は、脂質栄養学会編集委員会の Facebook サイト

（https://www.facebook.com/jsln1992）からお寄せ頂きたいと思いますが、日本脂質 栄養学会のホームページ (http://jsln.umin.jp/) でご案内する予定ですので、その案 内をご覧頂いてから Facebookにアクセスをお願いします。

\section{改正を求める栄養成分（脂質）表示の項目とその必要性について}

\section{I 栄養成分（脂質）表示改正を求める項目}

日本脂質栄養学会は、発足以来、油脂を構成する主要な脂肪酸を 4 群 \{下記 （1）〜（4）＼$に分け、栄養学的評価をしてきた。厚生労働省「日本人の食事摂取 }$ 基準」も、この 4 分類を採択している（2015 年版参照）。

以下に、栄養成分としてのこれらの表示の必要性に加え、コレステロール、トラン ス脂肪酸、共役リノール酸にかかわる表示の必要性について説明する。

\section{（1） 飽和脂肪酸群、および}

\section{（2）一価不飽和脂肪酸（オレイン酸等）群}

これらは動物性脂肪および数種の植物油脂の主成分であり、主にエネルギー源とし て、また細胞膜構成分として利用される。これらの摂取を増やしても長期的にはコレ ステロール值が上がることはなく、冠動脈心疾患を増や寸こともない（1）。逆に飽 和脂肪酸の摂取が多い群ほど脳卒中(虚血性)が少なく、飽和脂肪酸やコレステロール が脳卒中の防御因子であることが内外の臨床試験で明らかにされている（1）。した 
がってこれらの摄取上限を定める必要はないが、過剩摂取によるエネルギー過多にな らないよう留意する必要はある。栄養成分としての表示の必要性は比較的低い。

\section{（3）リノール酸、アラキドン酸などの n-6（あるいは $\omega 6$ ）群}

リノール酸は動物体内では作られないが、動物が摂取すると体内でアラキドン酸が 生成する。この群は動物の成長、生殖生理などに必須であり、一部は、ホルモン様物 質に変わる。しかし、必須量は摂取エネルギーの $1 \%$ 以下であり、通常の食環境で不 足することはない。

摂取過剩により心疾患、多種の癌、アレルギー性疾患、炎症性疾患などが増え、心 臓病が助長されることが明らかにされてきた（2-4）。また、コレステロールを下 げ、心血管系疾患のリスクを低減するとして、飽和脂肪酸の摂取を抑えてリノール酸 で補う食事指導が現在でさえ行われているが、冠血管疾患既往症のある患者を対象と した過去の研究の再評価では、リノール酸摂取による総死亡リスクの有意な上昇と、 心血管系疾患による死亡リスクの上昇傾向が確認された（5）。さらにこの介入試験 では、当初から、リノール酸摂取によるコレステロールの有意な低下にも関わらず総 死亡リスクの上昇が認められた。これは、冠血管疾患予防のために、「コレステロー ルと飽和脂肪酸の摂取減をめざし、高リノール酸油を増や寸こと」への疑問を投げか けるものである。現在の食環境では、リノール酸群の摂取過剩を抑制することが最も 重要であり、栄養成分としての表示が必須である（加工食品中のグラム数等）。日本 人の食事摂取基準の 2010 年版まではリノール酸の摂取目標量として $<10$ エネルギ 一\%という大きな值が設定されていたが、2015 年版ではそれが撤廃され、その約半分 にあたる量が目安量として設定された。

\section{（4） $\alpha$-リノレン酸、EPA（エイコサペンタエン酸）、DHA（ドコサヘキサエン}

\section{酸）などの $n-3 （$ あいは $\omega 3$ ）群}

$\alpha$-リノレン酸は動物体内では作られないが、動物が摂取すると一部は EPA や DHA に変わる。DHA は脳・網膜などの働きを正常に保つうえで必須である。

これら n-3 群のうち EPA はアラキドン酸（n-6）代謝と競合し、n-6 脂肪酸の過剩 摂取による各種疾患（上述）を抑制する作用が強い（6,7）。実際、EPA や DHA は 
高脂血症/閉塞性動脈硬化症の医薬品素材となっている。また、EPA および DHA を 含む食品には、特定保健用食品として許可されているものもある。

脳・網膜機能の維持における $\alpha$-リノレン酸群の必須量は $1 \%$ 以下であり、魚食摂取 の多い日本で欠乏することはまれであるが、全年齢にわたってn-3 群の摂取量を確保 することが求められている。「日本人の食事摂取基準」（2015 年版）では、n-3 系脂 肪酸の目安量が設定されている。以上に鑑み、栄養成分としての表示が必須である。

\section{（5）コレステロール}

コレステロール摂取総量に影響する食品は鶏卵（ $250 \mathrm{mg} / 60 \mathrm{~g} /$ 個）、牛・豚肉（65 〜 $75 \mathrm{mg} / 100 \mathrm{~g})$ 、バター $(20 \mathrm{mg} / 10 \mathrm{~g})$ などが主である。腸管吸収率が $50 \%$ 強なの で、通常の食事でこれら食品から吸収される量は約 $170 \mathrm{mg} /$ 日となる。鶏卵を毎日 2 個摂ると約 $300 \mathrm{mg} /$ 日に相当する。

これに対し、体内でのコレステロール生合成量は $1,200 \mathrm{mg} /$ 日ほどであり（8）、 身体は平均摂取（吸収）量の 4 倍を必要としている。コレステロールは摂取量が多い ほど脳卒中死亡率が低く、高コレステロール值は冠疾患の原因因子とはなっていない

（1）。このような背景から、コレステロールの摄取減をめざした表示は必要ない。 また、コレステロール低下食品（トクホ）は再評価が必要であり、“コレステロール ゼロ”を標榜することには問題がある。従来のようなリスク因子としてではなく、防 御因子であることを消費者に十分周知させ、栄養成分の表示に含めるべきである。 例：コレステロール $100 \mathrm{mg} / 100 \mathrm{~g}$ (成人一日必要量の 8.3\%)

\section{（6）トランス脂肪酸}

液体の植物性、動物性油脂に触媒を使って水素添加すると融点が上がるが、水素添 加の程度を調節することによって、適度な硬さ、よい呈味性の油脂を作ることができ る。これがマーガリンやファットスプレッド、フレッシュ（コーヒーなどに入れるク リーム)、ホイップクリームなどとして多くの食品に使われている。しかし、水素添 加（水添と略）の際に、天然には少ないトランス型の脂肪酸が副生する。これが一過 性に LDL-C 值を上げ HDL-C 值を下げるので冠疾患の危険因子と見做され、欧米で はその規制が進んでいる。 
反忽胃動物の胃中の微生物により、類似の水添反応が起るので、反忽胃動物由来の 食品にもトランス脂肪酸は含まれている。しかし、これらの食品中のトランス脂肪酸 は欧米の規制の対象にはなっていない。

トランス脂肪酸を規制する根拠として LDL-C/HDL-C 比の上昇が挙げられている が、薬で LDL-C/HDL-C 值を下げても冠疾患予防はできないこと（1）から、コレス テロールに関連づけた規制の根拠は科学的に強いものではない。

しかし植物油の水添では、トランス脂肪酸のほかに血液凝固に必要なビタミン $\mathrm{K} 1$ も水添され、血液凝固活性の弱いジヒドロビタミン型 K1 となる。一方、ビタミン $\mathrm{K} 1$ は体内で K2 に変換され、細胞間物質（マトリックスタンパク質）の活性化や骨 代謝に必須のオステオカルシンの活性化に役割を果たしている。ジヒドロ型ビタミン $\mathrm{K} 1$ は吸収されるが体内で $\mathrm{K} 2$ に変換されず、組織のビタミン $\mathrm{K} 2$ レベルを下げ、組織 のビタミン K2 不足を生じさせる $(9,10)$ 。大豆油や菜種油はビタミン K1 の供給源 として重要であるが、水添により上記のような影響が懸念されるため、このような水 添による副生物生成の指標としての意味も含め、トランス脂肪酸を栄養成分の表記に 含めることは必要である。

\section{（7）共役リノール酸（炭素鎖長 18 でシス型およびトランス型の共役二重結合}

\section{をもつもの)}

ザクロ種子、酪農製品などに見いだされているが、高リノール酸油をアルカリ処理 することによっても作られる。共役リノール酸は現時点では主に健康食品としてダイ エットに有効であるとされている。しかし長期摂取時の安全性が確保されていない。

現在、異性体についての栄養効果の比較研究が進んでいるが、その結果は「共役リ ノール酸として一括りにすることはできない」ことを示している。例えば鶏受精卵の 孵化に影響が認められるが、c9、t12 異性体が安全であるのに対し、 $c 10 、 t 12$ は孵化 率を 90\%以上低下させる（11）。原因の一つとして血管新生の阻害があるが、この 場合、 $c 9 、 t 11$ 異性体と $t 10 、 c 12$ 異性体はともに阻害作用を示している（12）。前 立腺癌細胞の増殖を抑制するとき、 $c 9 、 t 12$ 異性体はアラキドン酸カスケードを抑制 し、 $t 10 、 c 12$ 異性体はアポトーシスや細胞増殖サイクルを変える（13）。

共役リノール酸および共役リノレン酸（炭素鎖長 18 でシス型およびトランス型の 二重結合を 3 個持つもの）の研究は進展中であり一般食品の表示には時期尚早である 
が、健康食品の表示には異性体組成を含む表示が必要であり、その長期摂取により有 害作用があらわれる可能性については、注意を喚起する必要がある。

\section{II 原材料名 (脂質性) 表示の問題}

現在、加工食品の原材料名（脂質性）の表示は、油脂栄養の専門家でも正確に理解 できないほど複雑である。加工食品の原材料名中に加工食品名が使われたり、定義が 明確でないカタカナ表示の原材料名が多く使われたりしている。その結果、例えばト ランス脂肪酸を含む原材料がいくつかに分散され、その含有量が推測できないように なっている。

食品の原材料名は消費者がそれを選択する場合の参考に供されるものであるから、 一般消費者がわかるものでなければならない。この原則に基づいて、次のような表示 の改正が必要である。

\section{（1）油種（油脂の種類）の表示の必要性 - 植物油脂中の微量成分の問題}

油脂の栄養評価は、従来、主として脂肪酸組成に基づいて行われてきた。しかし、 脂肪酸組成のみでは説明できない生理作用が、動物実験で明らかになってきた。例え ば菜種（カノーラ種）油は大豆油に比べn-3/n-6 比が高く、この值の高いシソ油・エ ゴマ油同様に、大豆油に比べ脳卒中易発症高血圧自然発症ラット（以下、脳卒中ラッ トと略）の寿命を延長することが期待された。しかし菜種油は在来種、カノーラ種と もに、また製法などにもかかわらず、脳卒中ラットの寿命を顕著に短縮することが明 らかにされた（14）。分画により寿命短縮活性の弱い菜種油画分が得られること、加 水分解により得られる遊離脂肪酸画分には寿命短縮活性が無いことから、菜種油中の 微量成分による有害効果と解釈されている。この微量成分は同定されていないが、菜 種油の寿命短縮作用はカナダ政府研究機関（Health Canada）でも確認されている。 菜種油のほかオリーブ油、コーン油、高オレイン酸型ベニバナ油、パーム油、水添大 豆油、水添菜種油など数種の植物油脂が、大豆油に比べ脳卒中ラットの寿命を異常に 短縮する。シソ油・エゴマ油、亜麻仁油、バター、ラードなどは、この動物モデルで 相対的な寿命短縮を認めない。 
一方、オリーブ油やパーム油はラットにおいて用量依存的に発癌促進作用を示し、 この作用も脂肪酸組成では説明できず、微量成分によると解釈されている（15, 16) 。

実験動物で認められる作用がヒトでも見られるか否かを検証することは難しい。し かし、実験動物での有害効果が報告されているこれらの植物油の安全性評価には慎重 でなければならないと同時に、誰もがその情報に接することができる以上、油脂性原 材料名には菜種油、水添大豆油、シソ油、バターなど油種名を、消費者に分かり易く 明示することが必須である。「食用油脂」、「植物油脂」、「食用植物油脂」などの 用語は原材料名として使うべきではない。

（2）カタカナ表記の食品等を原材料名として表示する際の問題およびカタカ ナ表記食品の原材料表示の問題

\section{原材料名として用いられる加工油脂名の表示}

マーガリン：これは加工食品である。水添植物油を使う一般のマーガリンのほ かエステル交換により油質を改変したマーガリン、水添魚油素材のマーガリン、 パーム油などのトロピカルオイル使用のマーガリンなど、原料が多岐にわたるマ 一ガリンが市場に出ていると推測できる。加工食品の原材料名に、加工食品であ るマーガリンを使うべきではなく、使用した油種名を表示すべきである。

食用精製加工油脂（加工油脂）：従来は水添植物油脂を示寸用語であると理解 されていたが、現在ではエステル交換によるものも含まれている。この原材料名 の示寸物質は食品により異なっている場合があり、原材料名として使うべきでは ない。使用した油種名を表記すべきである。

ショートニング：常温で半固形状の油脂であり主として植物性であるが、動物 性脂肪を加えたものもある。成分の大部分が油脂なので、原材料名としての「シ ヨートニング」の使用をやめ、油種名を表示すべきである。あるいは油種名をカ ッコ内につける。

例；ショートニング (パーム油)

ファットスプレッド：油脂を主成分とするスプレッド用の加工食品なので、原 材料名としての「ファットスプレッド」の使用をやめ、油種名を表示するか、あ るいは油種名をカッコ内につけるべきである。 


\section{油脂を使用した食品の原材料表示}

ホイップクリーム：わが国ではほとんどが植物油を原料とする。油種名を表記 するべきである。あるいは油種名をカッコ内につける。

コーヒーなどのフレッシュ：生クリームを使ったものもあるが、大部分は植物 性なので、油種名を表記するべきである。現在、小分けしたものには表示義務が ないようであるが、商品によって成分がまったく異なる場合があるので、表示が 必要である。

ソフトクリーム：油脂分として生クリーム 100\%のものから植物油脂 $100 \%$ のも のまであり、油種名の表記が必須である。コーンを容器とする場合は、コーンに 巻く紙に油種名の表記を含める。

マヨネーズ : 植物油脂が $65 \%$ 以上なので、油種名の表記が必須である。

サラダクリーミードレッシング（マヨネーズ様ドレッシング）：ノンオイル型 を除き、油脂の含量と油種名の表記を必須である。

\section{参考文献}

（1）日本脂質栄養学会・コレステロールガイドライン策定委員会監修＼cjkstart長寿のための コレステロール ガイドライン

(2) Muldoon MF, Manuck SB, Matthews KA.: Lowering cholesterol concentrations and mortality: a quantitative review of primary prevention trials. British Med J 1990, 301(6747): 309-314.

(3) Nkondjock A, Shatenstein B, Maisonneuve P, Ghadirian P.: Assessment of risk associated with specific fatty acids and colorectal cancer among French-

Canadians in Montreal: a case-control study. Int J Epidemiol. 2003, 32(2): 200209.

(4) Hibbeln JR, Nieminen LR, Lands WE: Increasing homicide rates and linoleic acid consumption among five Western countries, 1961-2000. Lipids. 2004, 39(12): 1207-1213. 
(5) Ramsden CE, Zamora D, Leelarthaepin B, Majchrzak-Hong SF, Faurot KR, Suchindran CM, Davis JM, Hibbeln JR.: Use of dietary linoleic acid for secondary prevention of coronary heart disease and death: evaluation of recovered data from the Sydney Diet Heart Study and updated meta-analysis. BMJ 2013; 346: e8707; (Published 05 February 2013)

(6) Chavarro JE, Stampfer MJ, Hall MN, Sesso HD, Ma J.: A 22-y prospective study of fish intake in relation to prostate cancer incidence and mortality. Am J Clin Nutr. 2008. 88(5): 1297-1303.

(7) Wakai K, Tamakoshi K, Date C, Fukui M, Suzuki S, Lin Y, Niwa Y, Nishio K, Yatsuya H, Kondo T, Tokudome S, Yamamoto A, Toyoshima H, Tamakoshi A; JACC Study Group. Dietary intakes of fat and fatty acids and risk of breast cancer: a prospective study in Japan. Cancer Sci. 2005, 96(9): 590-599.

(8) Nestel PJ, Whyte HM, Goodman DS: Distribution and turnover of cholesterol in humans. J Clin Invest.1969, 48(6): 982-991.

(9) Booth SL, Lichtenstein AH, O'Brien-Morse M, McKeown NM, Wood RJ, Saltzman E, Gundberg CM. Effects of a hydrogenated form of vitamin K on bone formation and resorption. Am J Clin Nutr. 2001, 74(6): 783-790.

(10) Sato T, Ozaki R, Kamo S, Hara Y, Konishi S, Isobe Y, Saitoh S, Harada H. The biological activity and tissue distribution of 2',3'-dihydrophylloquinone in rats. Biochim Biophys Acta. 2003, 1622(3):1 45-150.

（11）山下裕昭. 農業研究成果情報 No.317（平成 19 年 7 月）分類コード $09-16$ 熊本 県農林水産部

(12) Masso-Welch PA, Zangani D, Ip C, Vaughan MM, Shoemaker SF, McGee SO, Ip MM. Isomers of conjugated linoleic acid differ in their effects on angiogenesis and survival of mouse mammary adipose vasculature. J Nutr. 2004, 134(2): 299-307.

(13) Ochoa JJ, Farquharson AJ, Grant I, Moffat LE, Heys SD, Wahle KW. Conjugated linoleic acids (CLAs) decrease prostate cancer cell proliferation: different molecular mechanisms for cis-9, trans-11 and trans-10, cis-12 isomers. Carcinogenesis. 2004, 25(7): 1185-1191. 
(14) Huang MZ, Watanabe S, Kobayashi T, Nagatsu A, Sakakibara J, Okuyama H. Unusual effects of some vegetable oils on the survival time of stroke-prone spontaneously hypertensive rats. Lipids. 1997, 32(7): 745-751.

(15) Onogi N, Okuno M, Komaki C, Moriwaki H, Kawamori T, Tanaka T, Mori H, Muto Y. Suppressing effect of perilla oil on azoxymethane-induced foci of colonic aberrant crypts in rats. Carcinogenesis. 1996, 17(6): 1291-1296.

(16) Narisawa T, Takahashi M, Kotanagi H, Kusaka H, Yamazaki Y, Koyama H, Fukaura Y, Nishizawa Y, Kotsugai M, Isoda Y, et al. Inhibitory effect of dietary perilla oil rich in the n-3 polyunsaturated fatty acid alpha-linolenic acid on colon carcinogenesis in rats. Jpn J Cancer Res. 1991, 82(10): 1089-1096. 